\title{
Pengaruh Intensitas Pengungkapan dalam Sustainability Report dan Return On Asset pada Return Saham
}

\author{
I Kadek Bayu Putra Nusantara ${ }^{1}$ \\ Fakultas Ekonomi dan Bisnis \\ Universitas Udayana, Indonesia. \\ Email: bayuputra_nusantara@yahoo.com
}

\author{
I Made Mertha ${ }^{2}$ \\ Fakultas Ekonomi dan Bisnis \\ Universitas Udayana, \\ Indonesia.
}

\begin{abstract}
ABSTRAK
Populasi penelitian adalah seluruh perusahaan yang terdaftar di Bursa Efek Indonesia (BEI) pada tahun 2014 sampai dengan 2017 yang menerbitkan sustainability report. Sampel ditentukan dengan teknik purposive sampling dengan kriteria yang tidak termasuk perusahaan keuangan dan perusahaan yang menerbitkan laporan keberlanjutan (sustainability report) periode 2014-2017 berturut-turut sehingga diperoleh sampel sebanyak 15 perusahaan. Teknik analisis yang dilakukan adalah Analisis Regresi Linear Berganda. Hasil analisis menunjukkan bahwa tidak terdapat pengaruh antara hubungan intensitas pengungkapan dalam sustainability report pada return saham sedangkan. Pengujian pada hipotesis kedua mendapatkan hasil bahwa terdapat pengaruh antara hubungan return on asset pada return saham yang akan diterima perusahaan. Investor dalam berinvestasi di pasar modal diharapkan memerhatikan kondisi-kondisi di dalam perusahaan seperti ROA agar mendapatkan return saham yang diinginkan.
\end{abstract}

Kata Kunci : Sustainability report, return on asset, return saham.

\section{Effects of Disclosure Intensity in Sustainability Reports and Return On Assets on Stock Returns}

\begin{abstract}
The research population is all companies listed on the Indonesia Stock Exchange (IDX) from 2014 to 2017 that issued sustainability reports. The sample is determined by purposive sampling technique with criteria that do not include financial companies and companies that publish sustainability reports for the 2014-2017 period in a row to obtain a sample of 15 companies. The analysis technique used is Multiple Linear Regression Analysis. The results of the analysis show that there is no influence between the relationship between the intensity of disclosure in the sustainability report on stock returns while. Tests on the second hypothesis get the result that there is an influence between the relationship of return on assets to the stock returns that the company will receive. Investors in investing in the capital market are expected to pay attention to conditions in the company such as ROA in order to get the desired stock return.
\end{abstract}

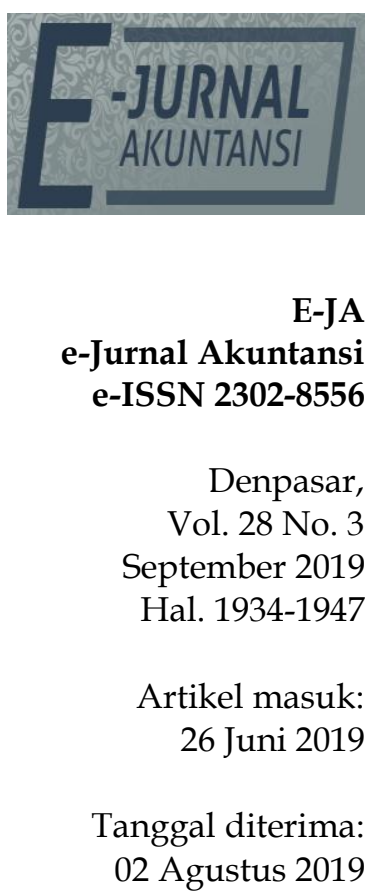

Keywords : $\quad$ Sustainability report, asset returns, stock returns. 


\section{PENDAHULUAN}

Indonesia menjadi salah satu pilihan utama bagi investor untuk menanamkan dananya. Semakin banyaknya investor yang memasuki pasar modal Indonesia membuat perusahaan-perusahaan yang telah go public memiliki persaingan untuk berlomba-lomba mendapatkan tambahan dana dari investor. Investor dalam berinvestasi tentu memiliki pertimbangan mengenai pemilihan perusahaan yang akan diinvestasikan. Investor memerlukan informasi yang pada akhirnya akan mempengaruhi keputusannya dalam berinvestasi. Investor menilai kinerja perusahaan dan menilai bagaimana kelangsungan perusahaan kedepannya untuk menentukan layak tidaknya untuk berinvestasi pada perusahaan tersebut. Tanggapan dari investor setelah melakukan penilaian tersebut dapat dilihat dari reaksi pasar. Return sahammenjadi salah satu faktor yang penting untuk dipertimbangkan. Hasil yang didapatkan setelah melakukan investasi merupakan yang dimaksud dengan return saham. Returndapat diartikan sebagai imbalan yang diberikan oleh perusahaan kepada investor karena telah memilih untuk berinvestasi meskipun terdapat risiko investasi yang mungkin harus ditanggung oleh investor tersebut. Returndapat mempengaruhi keputusan investor dalam menentukan pilihan perusahaan mana yang akan diberikan dana oleh investor (Bisara, 2015).

Profit suatu perushaan tentunya menjadi hal yang sangat diperhatikan oleh investor. Return saham dapat dipengaruhi oleh banyak hal, salah satunya adalah profit. Tanggung jawab sosial yang dilakukan perusahaan kepada lingkungan sekitarnya dan kepada pemegang saham juga dapat menjadi pertimbangan dalam return saham. Perlu adanya tanggung jawab oleh perusahaan kepada lingkungan sekitar tempatnya beroperasi. Dampak-dampak tertentu yang dapat mengubah atau bahkan merusak lingkungan sekitar tempat beroperasinya perusahaan dapat memberikan dampak buruk juga bagi citra perusahaan. Reaksi negatif dari pasar sangat mungkin terjadi ketika pasar mengetahui dampak buruk yang diakibatkan oleh perusahaan pada lingkungan sekitarnya. Contoh nyata dari kejadian kerusakan lingkungan yang dilakukan oleh perusahaan adalah kerusakan yang dilakukan oleh PT. Freeport karena membuang limbah di lingkungan sekitar tempat operasi perusahaan yang kemudian merugikan rakyat Papua dan bahkan merugikan negara (Irfany, 2017).

Pengungkapan tanggung jawab sosial dan lingkungan merupakan hal penting yang perlu diungkapkan. Pengungkapan ini dituangkan dalam sustainability reportatau pelaporan berkelanjutan. Dalam pelaporan berkelanjutan melaporkan tidak hanya keadaan keuangan perusahaan namun dilaporkan juga bagaimana kinerja sosial dan lingkungan perusahaan. Perusahaan yang memiliki intensitas tinggi dalam melakukan pengungkapan sustainability report cenderung mendapatkan reaksi yang positif dari pasar dari pada perusahaan yang memiliki intensitas yang rendah dalam melakukan pengungkapan sustainability report.

Penelitian sebelumnya yang dilakukan oleh Prayosho \& Hananto (2013), Canisie (2014) dan Wijaya (2017) tidak menemukan adanya pengaruh dari sustainability report pada return saham. Budiman \& Supatmi (2009) pada penelitiannya yang mengangkat topik yang sama namun mendapatkan hasil yang berbeda yaitu ditemukannya pengaruh antara sustainability report pada return saham. 
Ketika akan berinvestasi investor tentunya perlu mengetahui dengan jelas bagaimana keadaan perusahaan yang akan dipilih. Informasi yang diberikan kepada pihak eksternal seperti investor perlu dianalisis lebih lanjut agar keputusan yang nantinya diambil tidak menyesatkan dan merugikan investor. Analisis ini salah satunya dapat dilakukan dengan menggunakan rasio keuangan. Terdapat berbagai jenis rasio tapi pada penilitian ini rasio yang akan difokuskan adalah rasio profitabilitas. Rasio profitabilitas memberikan gambaran kepada pengguna rasio mengenai bagaiman perusahaan mendapatkan laba untuk perusahaan. Penilaian yang dilakukan oleh rasio ini tidak hanya pada segi kemampuan dalam memperoleh keuntungan tetapi juga bagaimana perusahaan mengelola perusahaan. Dari rasio ini investor dapat menilai seberapa efektif perusahaan dalam mengelola organisasinya (Weston \& Copeland, 2010).

Rasio profitabilitas terdiri dari beberapa jenis rasio dan yang digunakan sebagai proksi kinerja adalah Return On Asset atau ROA. Perhitungan kinerja dengan ROA melihat bagaimana perusahaan mengelola aset yang dimilikinya yang kemudian akan mencermin efisiensi dari perusahaan tersebut. Pengukuran profit menggunakan ROA adalah dengan membandingkan laba bersih setelah pajak dengan total asset (Kurniatun et al., 2015). Putra \& Dana (2013), Putra et al,(2018) dan Setiyono \& Amanah (2016)dalam penelitian yang dilakukannya menyatakan bahwa Return On Assets tidak berpengaruh terhadap return saham. Terdapat inkonsistensi hasil dari beberapa penelitian sebelumnya yang mengangkat topik mengenai hubungan antara ROA pada return saham. Saragih (2018) dan Aldiena \& Hakim (2019) menemukan adanya hubungan negatif antara ROA pada return saham. Hasil sebaliknya ditemukan oleh Nadiyah \& Bambang (2017), Pratiwi \& Putra (2015) dan Maryyam (2016) yang menemukan bahwa terdapat pengaruh positif antara ROA pada return saham.

Teori sinyal memberikan penjelasan mengenai alasan dibalik pengungkapan informasi oleh manajemen perusahaan. Pengungkapan informasi ini dilandasi karena adanya asimetri informasi dimana antara pihak satu dan lainnya tidak memiliki pengetahuan mengenai informasi yang sama. Satu ihak dapat memiliki informasi yang tidak dimiliki pihak lainnya hal inilah yang menimbulkan asimetri informasi. Dalam hubungannya antara perusahaan dengan investor, manajemen perusahaan merupakan pihak yang memiliki informasi yang lebih relevan mengenai keadaan perusahaan sedangkan investor tidak memiliki informasi sebanyak yang dimiliki oleh manajemen perusahaan. Dalam pelaporan berkelanjutan melaporkan tidak hanya keadaan keuangan perusahaan namun dilaporkan juga bagaimana kinerja sosial dan lingkungan perusahaan. Perusahaan yang memiliki intensitas tinggi dalam melakukan pengungkapan sustainability report cenderung mendapatkan reaksi yang positif dari pasar dari pada perusahaan yang memiliki intensitas yang rendah dalam melakukan pengungkapan sustainability report.

Rasio profitabilitas dapat dihitung dengan Return on Asset (ROA). Perhitungan kinerja dengan ROA melihat bagaimana perusahaan mengelola aset yang dimilikinya yang kemudian akan mencermin efisiensi dari perusahaan tersebut. Prastowo (2011) dan Tandelilin(2010) memiliki pengertian yang serupa 
mengenai ROA yaitu bagaimana perusahaan mengelola asset yang dimiliki oleh perusahaan dan kemudian dapat menghasilkan laba bagi perusahaan tersebut.

Return saham menjadi salah satu faktor yang penting untuk dipertimbangkan. Hasil yang didapatkan setelah melakukan investasi merupakan yang dimaksud dengan return saham. Returndapat diartikan sebagai imbalan yang diberikan oleh perusahaan kepada investor karena telah memilih untuk berinvestasi meskipun terdapat risiko investasi yang mungkin harus ditanggung oleh investor tersebut. Returndapat mempengaruhi keputusan investor dalam menentukan pilihan perusahaan mana yang akan diberikan dana oleh investor (Bisara, 2015). Terdapat beberapa penelitian sebelumnya yang mengangkat topik mengenai intensitas pengungkapan dalam sustainability report pada return saham. Budiman \& Supatmi (2009) mendapatkan hasil yaitu ditemukannya pengaruh antara hubungan intensitas pengungkapan dalam sustainability report pada return saham.

$\mathrm{H}_{1}$ : Intensitas pengungkapan dalam sustainability report berpengaruh positif pada return saham.

Ketika akan berinvestasi investor tentunya perlu mengetahui dengan jelas bagaimana keadaan perusahaan yang akan dipilih. Informasi yang diberikan kepada pihak eksternal seperti investor perlu dianalisis lebih lanjut agar keputusan yang nantinya diambil tidak menyesatkan dan merugikan investor. Analisis ini salah satunya dapat dilakukan dengan menggunakan rasio keuangan. Terdapat berbagai jenis rasio tapi pada penilitian ini rasio yang akan difokuskan adalah rasio profitabilitas. Rasio profitabilitas memberikan gambaran kepada pengguna rasio mengenai bagaiman perusahaan mendapatkan laba untuk perusahaan. Penilaian yang dilakukan oleh rasio ini tidak hanya pada segi kemampuan dalam memperoleh keuntungan tetapi juga bagaimana perusahaan mengelola perusahaan. Dari rasio ini investor dapat menilai seberapa efektif perusahaan dalam mengelola organisasinya(Weston \& Copeland, 2010).

Rasio profitabilitas terdiri dari beberapa jenis rasio dan yang digunakan sebagai proksi kinerja adalah Return On Asset atau ROA. Perhitungan kinerja dengan ROA melihat bagaimana perusahaan mengelola aset yang dimilikinya yang kemudian akan mencermin efisiensi dari perusahaan tersebut. Pengukuran profit menggunakan ROA dilakukan dengan melakukan perbandingan antara laba bersih setelah pajak dengan total asset (Kurniatun et al., 2015). Hasil sebaliknya ditemukan oleh Nadiyah \& Bambang (2017), Pratiwi \& Putra (2015), Maryyam (2016), Kurniatun et al. (2015) dan Geriadi \& Wiksuana (2017)yang menemukan bahwa terdapat pengaruh positif antara ROA pada return saham.

$\mathrm{H}_{2}$ : Return on Assetberpengaruh positif terhadap return saham.

\section{METODE PENELITIAN}

Bursa Efek Indonesia dipilih sebagai lokasi penelitian. Penelitian dilakukan pada perusahaan-perusahaan yang terdaftar di Bursa Efek Indonesia (BEI) selama 4 tahun dengan periode 2014 sampai dengan 2017.Web resmi dari BEI yaitu www.idx.co.id merupakan lokasi penelitian ini.Return saham perusahaanperusahaan yang terdaftar di Bursa Efek Indonesia (BEI) dengan pengungkapan sustainability report dan ROA telah ditentukan sebagai objek untuk diteliti. 
Terdapat dua jenis variabel yang digunakan dalam penelitian ini yaitu variabel bebas atau independen dimana variabel ini mempengaruhi variabel lain yang dinamakan variabel terikat. sustainability report sebagai $X_{1}$ dan return on assetsebagai $X_{2}$ merupakan dua variabel bebas yang digunakan dalam penelitian ini sedangkan variabel terikat yaitu Return saham sebagai $Y$.

Proksi yang digunakan untuk mengukur sustainability reporta dalah Sustainability Report Disclosure Index atau SRDI. Terdapat dua jenis standar dalam melakukan pengungkapan dalam praktik pelaporan. Standar yang pertama adalah standar umum dan kedua adalah standar khusus. Jenis pengungkapan yang digunakan adalah pengungkapan berstandar khusus. Standar khusus dipilih karena memberikan penjabaran lebih jelas mengenai ekonomi, sosial dan lingkungan dari pada standar umum. Berikut adalah perhitungan yang dapat digunakan untuk memperoleh.

$$
\mathrm{SRDI}=\frac{n}{k}
$$

Keterangan:

$$
\begin{array}{lll}
\mathrm{SRDI} & =\text { Sustainability Reporting Disclosure Index } \\
\mathrm{n} & =\text { Jumlah total indikator yang diungkapkan perusahaan } \\
\mathrm{k} & =\text { Jumlah indikator yang diharapkan berdasarkan pada } \\
& \quad \text { kriteriapelaporan opsi inti atau opsi komprehensif. }
\end{array}
$$

Rasio profitabilitas menghubungkan laba dengan besaran tertentu yaitu penjualan maupun modal atau aktiva yang digunakan untuk menghasilkan laba. Rasio profitabilitas dapat dihitung dengan Return on Asset (ROA) disebut juga sebagai rentabilitas ekonomi merupakan ukuran kemampuan perusahaan dalam mengasilkan laba dengan semua aktiva yang dimiliki oleh perusahaan (Tandelilin, 2010). Pengukuran profit menggunakan ROA dilakukan dengan melakukan perbandingan antara laba bersih setelah pajak dengan total asset (Kurniatun et al., 2015).

Salah satu faktor yang penting untuk dipertimbangkan adalah return saham. Hasil yang didapatkan setelah melakukan investasi merupakan yang dimaksud dengan return saham. Returndapat diartikan sebagai imbalan yang diberikan oleh perusahaan kepada investor karena telah memilih untuk berinvestasi meskipun terdapat risiko investasi yang mungkin harus ditanggung oleh investor tersebut. Return saham dapat dihitung dengan rumus sebagai berikut (Jogiyanto, 2015):

$$
R_{t}=\frac{P_{t}-P_{t-1}}{P_{t-1}}
$$

Keterangan:

$R_{t} \quad=$ Return saham perusahaan i pada periode ke- $\mathrm{t}$

$P_{t} \quad=$ Harga saham penutupan perusahaan i pada periode $\mathrm{t}$

$P_{t-1} \quad=$ Harga saham penutupan perusahaan i pada periode $\mathrm{t}-1$

Dari seluruh perusahaan yang ada di Bursa Efek Indonesia periode 2014-

2017 didapatkan sampel sebanyak 15 perusahaan. Kelimabelas perusahaan ini terpilih menjadi sampel karena telah memenuhi syarat dari teknik pengambilan sampel yang digunakan yaitu purposive sampling. Metode pengumpulan data yang dipergunakan dalam penelitian ini adalah metode observasi nonpartisipan. Dalam metode ini, pengumpulan data yang dilakukan tidak terlibat secara langsungnamun hanya sebagai pengamat independen (Sugiyono, 2017). Selain 
metode observasi nonpartisipan, peneliti juga menggunakan metode dokumentasiData kuantitatif adalahhasil perhitungan dari data yang telah dikumpulkan.

Sumber data yang digunakan dalam penelitian ini adalah data sekunder. Data sekunder adalah data yang dikumpulkan oleh orang lain, bukan peneliti itu sendiri. Sumber data diperoleh dari laporan tahunan (Annual Report) dan laporan keberlanjutan (Sustainability Report) periode tahun 2014-2017 perusahaanperusahaan sampel yang diperoleh dari Bursa Efek Indonesia yang di dapat dari website perusahaan.

\section{HASIL DAN PEMBAHASAN}

Wilayah penelitian yang digunakan dalam penelitian ini adalah Bursa Efek Indonesia (BEI) yang berjumlah 50 perusahaan. Penelitian ini menggunakan sampel seluruh perusahaan yang menerbitkan Sustainability Report berturut-turut dari tahun 2014 hingga 2017. Sampel penelitian ditentukan dengan menggunakan teknik purposive sampling yaitu sampel dipilih dengan kriteria tertentu. Berdasarkan kriteria tersebut, maka perusahaan yang memenuhi kriteria adalah 15 perusahaan.Proses pemilihan sampel dengan berdasarkam kriteria yang telah ditentukan dapat dilihat dalam Tabel 1.

\section{Tabel 1. Hasil Seleksi Sampel Penelitian}

\begin{tabular}{cc} 
Kriteria & $\begin{array}{c}\text { Jumlah } \\
\text { Perusahaan }\end{array}$ \\
\hline $\begin{array}{l}\text { Jumlah perusahaan yang terdaftar di Bursa Efek Indonesia } \\
\text { yang menerbitkan SR hingga tahun 2017 }\end{array}$ & 49 \\
$\begin{array}{l}\text { Perusahaan yang termasuk sektor keuangan dan } \\
\begin{array}{l}\text { Perusahaan yang tidak menerbitkan Sustainability Report } \\
\text { berturut-turut pada periode 2014-2017 }\end{array}\end{array}$ \\
Jumlah Sampel Penelitian \\
Tahun Pengamatan \\
Jumlah Pengamatan dalam Empat Tahun Penelitian
\end{tabular}

Sumber: Data Penelitian,2019

Statistik deskriptif digunakan untuk memberikan deskripsi suatu data dilihat dari rata-rata (mean), deviasi standar (standard deviation), maksimum (max) dan minimum (min). Berdasarkan Tabel 2,return saham (Y) menunjukkan nilai rata-rata sebesar 0,3176. Nilai deviasi standar return saham sebesar 0,18464, nilai ini lebih kecil dibandingkan dengan nilai rata-rata. Hal ini menunjukkan bahwa sebaran data return saham memiliki rentang data yang rendah antara data satu dengan lainnya. Return saham sebesar maksimal bernilai 0,96 dan return saham minimum sebesar 0,09. 
Tabel 2. Hasil Analisis Statistik Deskriptif

\begin{tabular}{cccccc}
\hline Variabel & N & Min. & Max. & Mean & $\begin{array}{c}\text { Std. } \\
\text { Deviation }\end{array}$ \\
\hline $\begin{array}{c}\text { Return Saham }(\mathrm{Y}) \\
\text { Intensitas Pengungkapan } \\
\text { dalam SR }\left(\mathrm{X}_{1}\right)\end{array}$ & 60 & 0,09 & 0,96 & 0,3176 & 0,18464 \\
ROA $\left(\mathrm{X}_{2}\right)$ & 60 & -5.72 & 19,11 & 4,9670 & 5,99425 \\
& & & & & \\
\end{tabular}

Sumber: Data Penelitian,2019

Berdasarkan Tabel 2,return saham $(\mathrm{Y})$ menunjukkan nilai rata-rata sebesar 0,3176 . Nilai deviasi standar return saham sebesar 0,18464 , nilai ini lebih kecil dibandingkan dengan nilai rata-rata. Hal ini menunjukkan bahwa sebaran data return saham memiliki rentang data yang rendah antara data satu dengan lainnya. Return saham sebesar maksimal bernilai 0,96 dan return saham minimum sebesar 0,09.

Intensitas Pengungkapan dalam Sustainability Report pada tahun 2014 sampai dengan 2017 rata- adalah sebesar 4,9670 dengan nilai deviasi standar sebesar 5,99425. Nilai deviasi standar yang lebih tinggi dari nilai rata-rata menunjukkan bahwa sebaran Intensitas Pengungkapan dalam Sustainability Reportmemiliki rentang data yang tergolong tinggi antara satu dengan data lainnya. Intensitas Pengungkapan dalam Sustainability Reportterendah sebesar 5,72 dan tertinggi sebesar 19,11.

Pada tahun 2014 sampai dengan 2017 Return On Asset memiliki nilai ratarata adalah 0,2388dengan nilai deviasi standar sebesar 1.02939. Nilai deviasi standar yang lebih tinggi dari nilai rata-rata menunjukkan bahwa sebaran ROAmemiliki rentang data yang tergolong tinggi antara satu dengan data lainnya. Nilai ROAterendah sebesar -0,80 dan tertinggi sebesar 5,41.

Uji normalitas bertujuan untuk mengetahui bahwa dari sampel data yang digunakan telah berdistribusi normal atau tidak. Model regresi yang baik adalah distribusi data normal atau mendekati normal. Jika tidak normal, maka prediksi yang dilakukan dengan data tersebut tidak akan baik, atau dapat memberikan hasil prediksi yang menyimpang (Ghozali \& Chairi., 2016).

Tabel 3. Hasil Uji Normalitas

\begin{tabular}{llr}
\hline & & Unstandardized Residual \\
\hline Normal Parametersa,b & Mean & 60 \\
& Std. Deviation & 0,0000000 \\
Most Extreme Differences & Absolute & 0,79055773 \\
& Positive & 0,147 \\
& Negative & 0,147 \\
Kolmogorov-Smirnov Z & & -0.108 \\
Asymp. Sig. (2-tailed) & & 1.136 \\
\hline
\end{tabular}

Sumber: Data Penelitian, 2019 
Uji normalitas dalam penelitian ini digunakan untuk menguji apakah model regresi, variabel independen dan variabel dependen keduanya memiliki distribusi normal atau tidak. Uji normalitas yang digunakan dalam penelitian ini adalah analisis grafik dan analisis data statistik dengan menggunakan Kolmogorov Smirnov Z (1-Sample K-S).

Tabel 3 menunjukkan nilai Asymp. Sig (2-tailed) sebesar 0,152 yang lebih besar daripada 0,05. Hal ini berarti bahwa model persamaan regresi dalam penelitian ini dengan menggunakan variabel dependen return saham sudah berdistribusi secara normal.

Uji multikolinearitas bertujuan untuk menguji apakah model regresi ditemukan adanya korelasi antara variabel bebas (Ghozali \& Chairi., 2016). Model regresi yang baik seharusnya tidak terjadi korelasi diantara variabel bebas. Jika suatu model regresi yang mengandung gejala multikolinearitas dipaksa untuk digunakan, maka akan memberikan hasil prediksi yang menyimpang. Untuk mendeteksi ada atautidaknya multikolinearitas di dalam model regresi adalah dengan melakukan teskorelasi antar variabel independen.

Tabel 4. Hasil Uji Multikolinieritas

\begin{tabular}{lcc}
\hline \multicolumn{1}{c}{ Variabel } & Tolerance & VIF \\
\hline Sustainability report $\left(\mathrm{X}_{1}\right)$ & 0,985 & 1,015 \\
Return on Asset $\left(\mathrm{X}_{2}\right)$ & 0,985 & 1,015 \\
\hline
\end{tabular}

Sumber: Data Penelitian,2019

Hasil yang didapatkan setelah melakukan pengujian multikolinearitas adalah tidak ditemukannya masalah multikolinearitas pada variabel-variabel bebas yang digunakan dalam model penelitian. Kesimpulan ini didapat dengan melihat niali tolerance yang dihasilkan dari uji multikolinearitas dimana masingmasing variabel memiliki nilai yang melebihi 0,1 serta memiliki nilai VIF yang kurang dari 10.

Uji autokorelasi digunakan untuk mengetahui ada atau tidaknya penyimpangan asumsi klasik autokorelasi yaitu korelasi yang terjadi antara residual pada satu pengamatan dengan pengamatan lain pada model regresi. Prasyarat yang harus terpenuhi adalah tidak adanya autokorelasi dalam model regresi. Gejala autokorelasi terjadi karena adanya korelasi antara anggota serangkaian observasi yang diurutkan menurut urutan waktu (time series). (Ghozali \& Chairi., 2016).

Tabel 5. Hasil Uji Autokorelasi

\begin{tabular}{cccccc}
\hline No & $\mathrm{dl}$ & $\mathrm{Du}$ & $4-\mathrm{du}$ & DW & Simpulan \\
\hline 1 & 1,5144 & 1,6518 & 2,3482 & 2,008 & Bebas autokorelasi \\
\hline \multicolumn{4}{l}{ Sumber: } \\
\hline
\end{tabular}

Tabel 5 menunjukkan bahwa besarnya nilai Durbin Watson sebesar 1,999. Nilai Durbin Watson menurut tabel dengan $\mathrm{n}=60$ dan $\mathrm{k}=2$ didapat nilai $\mathrm{dl}=1,5144$ dan nilai $\mathrm{du}=1,6518$. Oleh karena nilai $\mathrm{du}<\mathrm{dw}<(4-\mathrm{du})$ yaitu $(1,6518<2,008<2,3482)$, maka dapat disimpulkan tidak terdapat autokorelasi antar residual.

Uji ini bertujuan untuk menguji apakah dalam model regresi terjadi ketidaksamaan variance dari residual suatu pengamatan ke pengamatan yang lain (Ghozali \& Chairi., 2016). Model regresi yang baik adalah yang tidak mengandung gejala heteroskedastisitas atau mempunyai variance yang homogen. 
Jika variance dari residual satu pengamatan ke pengamatan yang lain tetap, maka disebut homokedastisitas dan jika berbeda disebut heteroskedastisitas.Dalam penelitian ini, cara untuk mendeteksi ada atau tidaknya heteroskedastisitasUji Glejser (Ghozali \& Chairi., 2016).

\section{Tabel 6. Hasil Uji Heterokedastisitas}

\begin{tabular}{llrrrrr}
\hline \multirow{2}{*}{ Model } & \multicolumn{2}{c}{$\begin{array}{c}\text { Unstandardized } \\
\text { Coefficients }\end{array}$} & \multicolumn{2}{c}{$\begin{array}{c}\text { Standardized } \\
\text { Coefficients }\end{array}$} & & \\
\cline { 2 - 4 } & \multicolumn{1}{c}{ B } & Std. Error & Beta & \multicolumn{1}{c}{ T } & \multicolumn{1}{c}{ Sig. } \\
\hline 1 & (Constant) & 0,551 & 0,073 & & 7.511 & 0,000 \\
& Sustainability Report & 0,100 & 0,080 & 0,160 & 1.248 & 0,217 \\
& ROA & $-0,097$ & 0,063 & $-0,199$ & -1.549 & 0,127 \\
\hline
\end{tabular}

Sumber: Data Penelitian, 2019

Setelah dilakukan pengujian heteroskedastisitas pada variabel sustainability report dan ROA didapatkan hasil yaitu masing-masing variabel terbebas dari gejala heteroskedastisitas. Hal ini dapat dilihat dari nilai signifikansi pada tiap variabel yang melebihi 0,05 .

Alat analisis dalam penelitian ini adalah analisis kuantitatif dengan menggunakanAnalisis Regresi Linier Berganda. Analisis ini memberikan penjelasanpada hasil pengujian masalah pada hipotesis dengan melakukan perhitungan danpembuktian data yang ada. Teknik analisis yang digunakan dalam menganalisis data regresi linear berganda diproses dengan menggunakan bantuan komputer dengan program SPSS.

Tabel 7. Hasil Analisis Regresi Linear Berganda

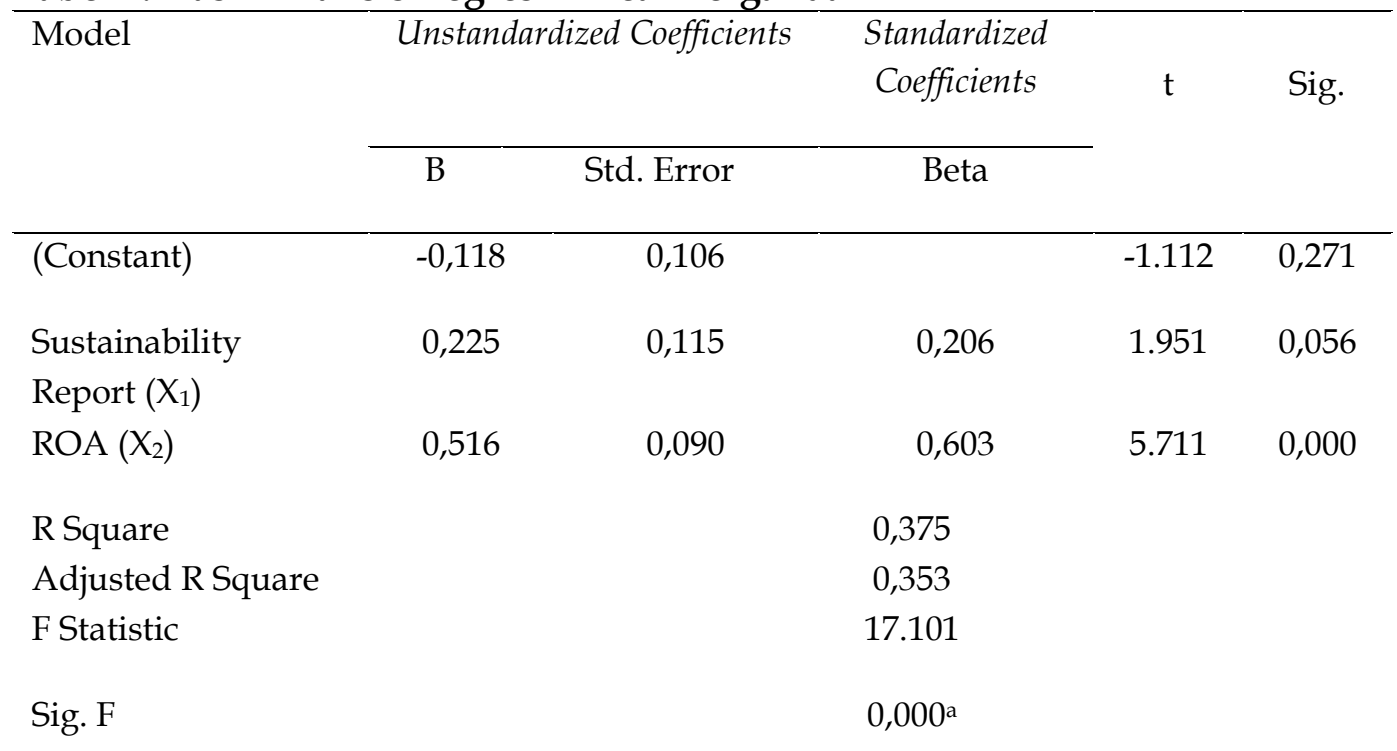

Sumber: Data Penelitian, 2019

Dari hasil analisis regresi linear berganda pada Tabel 7 dapat dibuat persamaan sebagai berikut:

$$
\mathrm{Y}=-0,118+0,225 \mathrm{X} 1+0,516 \mathrm{X} 2
$$

Nilai konstanta ( $\alpha$ ) sebesar $-0,118$ berarti apabila intensitas pengungkapan dalam sustainability report $\left(X_{1}\right)$, dan ROA $\left(X_{2}\right)$ bernilai 0 , maka return sahamakan cenderung menurun sebesar 0,118 satuan.Nilai koefisien regresi sustainability $\operatorname{report}\left(\beta_{1}\right)$ sebesar 0,225 berarti apabila apabila intensitas pengungkapan dalam 
sustainability report meningkat sebesar 1 satuan dengan anggapan variabel lainnya konstan, maka return saham perusahaan akan meningkat sebesar 0,225 satuan.Nilai koefisien regresi $\operatorname{ROA}\left(\beta_{2}\right)$ sebesar 0,516 berarti apabila ROA meningkat sebesar 1 persen dengan anggapan variabel lainnya konstan, maka return perusahaan akan meningkat sebesar 0,516persen.

Nilai Adjusted $\mathrm{R}^{2}$ yang didapatkan setelah melakukan uji koefisien determinasi yaitu 0,353.0,353 ini berarti sebesar 35,3 persen variasi return saham dipengaruhi oleh variabel sustainability report dan Return on Assetsedangkan sisanya sebesar 64,7 persen dijelaskan oleh faktor-faktor lain yang tidak dijelaskan dalam model penelitian.

Nilai $F$ hitung yang didapatkan setelah melakukan uji $F$ adalah 17,101. Didapatkan pula 0,000 sebagai nilai signifikansi P value. Nilai 0,000memiliki nilai yang lebih rendah dari niali a yang telah ditentukan yaitu 0,05 . nilai signifikansi $\mathrm{P}$ valueyang lebih rendah dari nilai a memiliki arti bahwa model yang digunakan pada penelitian ini adalah layak untuk digunakan.

Pengaruh Sustainability Report pada return saham $\left(\mathrm{H}_{1}\right)$. Hipotesis satu $\left(\mathrm{H}_{1}\right)$ menyatakan bahwa pengungkapan pada sustainability reportberpengaruh positif terhadap return saham perusahaan yang terdaftar di BEI. Analisis hipotesis menunjukkan bahwa pengungkapan pada sustainability report tidak berpengaruh pada return saham. Hasil tersebut tidak mendukung hipotesis pertama $\left(\mathrm{H}_{1}\right)$ yang menyatakan bahwa pengungkapan pada sustainability report berpengaruh pada return saham sehingga $\mathrm{H}_{1}$ ditolak.

Intensitas pengungkapan dalam sustainability report (SR) tidak diapresiasi oleh para investor secara keseluruhan sehingga tidak mampu mempengaruhi return saham perusahaan. Praktik pengungkapan SR di Indonesia masih tergolong baru dan jumlah perusahaan yang mengungkapkan SR masih sangat sedikit, sehingga para investor secara umum memandang SR masih belum mampu membawa dampak yang signifikan jika dimasukan kedalam pertimbangan untuk melakukan investasi. Informasi keuangan kemungkinan masih menjadi pertimbangan utama dari para investor pada umumnya untuk mengambil keputusan investasi. Dapat disimpulkan bahwa investor di Indonesia tidak memberikan reaksi terhadap informasi yang dihasilkan oleh praktek sustainability reporting. Kemungkinan besar hal ini terjadi karena investor di pasar modal Indonesia belum memahami pentingnya mengelolaperusahaansecara berklanjutan. Akibatnya, para investor belum memiliki kepedulian terhadap kinerja keberlanjutan perusahaan sehingga mereka pun tidak memiliki antusiasme terhadapinformasi terkaitaspek keberlanjutan perusahaan. Hal tersebut menunjukkan bahwa terdapatbanyak informasi lain,selainsustainability reportingyanglebihmempengaruhipertimbangan para investor di pasar modal Indonesiadalam membuat keputusan untuk berinvestasi seperti informasi keuangan perusahaan.Lorraine (2004), Canisie (2014), Prayosho \& Hananto (2013)pada penelitian sebelumnya dengan topik yang sama juga menunjukan bahwa pengungkapan SR tidak berpengaruh pada return saham ataupun abnormal return saham.

Pengaruh Return on Asset pada return saham $\left(\mathrm{H}_{2}\right)$. Hasil dari pengujian hipotesis kedua yaitu ditemukannya pengaruh antara ROApadaReturn saham. Hasil ini dapat dilihat dari nilai signifikansi yang kurang dari 0,05 yang berarti 
hipotesis kedua diterima. Pengaruh yang ditemukan adalah pengaruh positif dari $R O A$ pada Return saham. Pada analisis hipotesis dua didapatkan nilai koefisien regresi yang bernilai positif sebesar 0,516 nilai inilah yang menyatakan arah pengaruh positif dari $R O A$ pada Return saham.

Hipotesis dua $\left(\mathrm{H}_{2}\right)$ menyatakan bahwa ROA berpengaruh pada return saham perusahaan yang terdaftar di BEI. Analisis hipotesis menunjukkan bahwa ROA berpengaruh positif pada return saham. Hasil tersebut mendukung hipotesis kedua $\left(\mathrm{H}_{2}\right)$ yang menyatakan bahwa ROA berpengaruh pada return saham sehingga $\mathrm{H}_{2}$ diterima.

Teori Sinyal atau signalling theory memberikan penjelasan mengenai bagaimana informasi dapat memengaruhi keputusan investasi seseorang dan betapa pentingnya bagi perusahaan untuk menyajikan informasi agar tidak menyesatkan siappun yang akan menggunakan informasi yang diberikan oleh perusahaan. Perusahaan harus dapat menyediakan laporan yang tidak menyesatkan, dapat diandalkan, tepat waktu, memberikan informasi yang dibutuhkan oleh pengguna laporan keuangan dan harus disajikan secara tepat.

Tujuan utama investor melakukan investasi adalah untuk mendapatkan keuntungan atau profit. Perusahaan dapat memberikan sinyal kepada investor untuk menginvestasikan dananya dengan memperlihatkan kinerja keuangan dari perusahaan. Kinerja keuangan suatu perusahaan dapat dilihat dengan melakukan analisis rasio. Salah satu analisis yang dapat dilakukan adalah analisis rasio profitabilitas yaitu ROA.

Ketika akan berinvestasi investor tentunya perlu mengetahui dengan jelas bagaimana keadaan perusahaan yang akan dipilih. Informasi yang diberikan kepada pihak eksternal seperti investor perlu dianalisis lebih lanjut agar keputusan yang nantinya diambil tidak menyesatkan dan merugikan investor. Salah satu analisis yang dilakukan adalah analisis pada rasio keuangan. Terdapat berbagai jenis rasio tapi pada penilitian ini rasio yang akan difokuskan adalah rasio profitabilitas. Rasio profitabilitas memberikan gambaran kepada pengguna rasio mengenai bagaiman perusahaan mendapatkan laba untuk perusahaan. Penilaian yang dilakukan oleh rasio ini tidak hanya pada segi kemampuan dalam memperoleh keuntungan tetapi juga bagaimana perusahaan mengelola perusahaan. Dari rasio ini investor dapat menilai seberapa efektif perusahaan dalam mengelola organisasinya (Weston \& Copeland, 2010). Pratiwi \& Putra (2015), Kurniatun et al. (2015), Geriadi \& Wiksuana (2017), Nurhakim, Yunita, \& Iradianty (2016), Pramudi Yanto (2017), Kohansal et al. (2013) dalam penelitian yang dilakukannyamendapatkan hasil adanya pengaruh positif dari hubungan antara ROA pada return saham perusahaan. Hasil tersebut juga didukung dari penelitian yang dilakukan Mangkunegara \& Prabu (2006) pada perusahaan yang listing di Ftse-100 Index London bahwa ROA berpengaruh positif terhadap return saham.

Hasil penelitian mendukung teori sinyal yang memberikan penjelasan mengenai bagaimana informasi dapat memengaruhi keputusan investasi seseorang dan betapa pentingnya bagi perusahaan untuk menyajikan informasi agar tidak menyesatkan siapaun yang akan menggunakan informasi yang diberikan oleh perusahaan. Informasi mengenai ROA perusahaan dapat memberikan sinyal positif maupun negatif pada persepsi eksternal. Sinyal positif 
yang dihasilkan dari ROA akan berdampak pada meningkatnya minat investor pada perusahaan tersebut. Investor menilai sinyal positif yang dihasilkan oleh ROA tersebut dapat memberikan jaminan bahwa berinvestasi pada perusahaan yang memiliki kinerja yang baik sehingga kelangsungan hidup perusahaan tersebut juga baik. Respon positif dari investor ini memancing minat lebih banyak investor untuk berinvestasi yang kemudian berdampak pada meningkatnya harga saham.

Implikasi praktis dalam penelitian ini bagi investor dalam berinvestasi di pasar modal agar memperhatikan kondisi-kondisi di dalam perusahaan seperti ROA agar mendapatkan return saham yang diinginkan serta terhindar dari resiko yang akan timbul dari investasi.

\section{SIMPULAN}

Pengungkapan sustainability Report tidak berpengaruh pada return saham perusahaan yang terdaftar di Bursa Efek Indonesia. Hal ini menunjukkan bahwa semakin banyak atau sedikitnya pengungkapan dalam Sustainability Report tidak pengaruh pada return saham yang akan diterima investor.Return on Asset berpengaruh positif pada return saham perusahaan yang terdaftar di Bursa Efek Indonesia. Hal ini menunjukkan meningkatnya ROA menyebabkan peningkatan return saham yang akan diterima investor.

Terkait penelitian ini terdapat keterbatasan yaitu adanya variabel yang tidak berpengaruh berupa Sustainability Report sehingga peneliti dapat memberikan saran pada peneliti selanjutnya berupa peneliti selanjutnya dapat melakukan penelitian kembali dengan menggunakan sektor perusahaan pertambangan karena kegiatan usahanya dibidang atau berkaitan dengan sumber daya alam yang wajib menerbitkan sustainability report.

Terkait penelitian ini, bagi investor yang ingin berinvestasi diharapakan memperhitungkan ROA yang dihasilkan oleh perusahaan. Hal ini dikarenakan hasil penelitian menunjukkan bahwa ROA memiliki pengaruh pada return saham perusahaan yang terdaftar di BEI.

\section{REFERENSI}

Aldiena, E., \& Hakim, M. H. al. (2019). The Impact Of Companies' Internal Factors On The Performance Of Their Stock Returns. Journal of Islamic Economic Laws, 2(1), 120-149.

Bisara, C. (2015). Pengaruh Kinerja Keuangan Terhadap Return Saham. Skripsi Sekolah Tinggi Ilmu Ekonomi Indonesia (STIESIA). Surabaya.

Budiman, F., \& Supatmi. (2009). Pengaruh Pengumuman Indonesia Sustainability Reporting Award (ISRA) Terhadap Abnormal Return Dan Volume Perdagangan Saham (Studi Kasus Pada Perusahaan ISRA Periode 20052008). In Simposium Nasional Akuntansi XII. Palembang, 4-6 November 2009.

Canisie, B. (2014). Pengaruh Pengungkapan Sustainability Report Terhadap Perubahan Harga Saham Perusahaan. Skripsi Fakultas Ekonomi Jurusan Akuntansi Universitas Santa Dharma Yogyakarta.

Geriadi, M. A. D., \& Wiksuana., I. G. B. (2017). Pengaruh Inflasi Terhadap Return Saham Pada Perusahaan Properti Dan Real Estate yang Terdaftar Di Bursa Efek Indonesia (Risiko Sistematis Dan Profitabilitas Sebagai Variabel 
Mediasi). E-Jurnal Ekonomi Dan Bisnis Universitas Udayana, 6(9), 3435-3461.

Ghozali, I., \& Chairi. (2016). Teori Akuntansi. Semarang: Badan Penerbit Universitas Diponegoro.

Irfany, R. (2017). Dituding Rusak Lingkungan, Freeport Setor Kompensasi Rp 343, 13 M. Retrieved from https://bisnis.tempo.co/read/872120/dituding-rusaklingkungan-freeport-setor-kompensasi-rp-34313-m. Diakses 15 April 2019.

Jogiyanto. (2015). Teori Portofolio dan Analisis Investasi, edisi kesepuluh. Yogyakarta: BPFE.

Kohansal, M., Reza, A., Dadrasmoghaddam, Karmozdi, K. M., \& Mohseni, A. (2013). Relationship between Financial Ratios and Stock Prices for the Food Industry Firms in Stock Exchange of Iran. World Applied Programming, 3(10), $512-521$.

Kurniatun, M., Susanta, H., \& Saryadi. (2015). Pengaruh Current Ratio (CR), Debt To Equity Ratio (DER), Total Asset Turnover (TAT), Return On Asset (ROA), dan Price Earning Ratio (PER) Terhadap Return Saham (Pada Perusahaan Retail Yang Terdaftar Di Bursa Efek Indonesia 2010-2014). EJournal Administrasi Bisnis Universitas Diponegoro, 14(2), 1-19.

Lorraine. (2004). An Analysis of Stock Market Impact of Environmental Performance Information. Accounting Forum,28(1), 7-26.

Mangkunegara, A. A., \& Prabu, A. (2006). Evaluasi Kinerja SDM. Bandung: PT. Refika Aditama.

Maryyam, A. (2016). Impact Of Firms' Performance On Stock Returns (Evidence From Listed Companies Of Ftse-100 Index London, Uk). Global Journal of Management and Business Research: D Accounting and Auditing,16(1), 31-39.

Nadiyah, F., \& Bambang. (2017). Pengaruh Kinerja Keuangan dan Ukuran Perusahaan Terhadap Return Saham. Jurnal Ilmu Dan Riset Akuntansi Sekolah Tinggi Ilmu Ekonomi Indonesia (STIESIA) Surabaya.

Nurhakim, A., Yunita, I., \& Iradianty, A. (2016). The Effect of Profitability and Inflation on Stock Return at Pharmaceutical Industries at BEI in The Period of 2011-2014. Asia Pacific Institute of Advanced Research (APIAR), 2(2), 202210.

Pramudi Yanto, A. (2017). Analisis Pengaruh Inflasi, Suku Bunga BI, NPF dan FDR terhadap Profitabilitas (ROA) Bank Umum Syariah Periode 2012-2016. Skripsi IAIN Salatiga. Salatiga.

Prastowo, A. (2011). Metode Penelitian Kualitatif dalam Perspektif Rancangan Penelitian. Yogyakarta: Ar-Ruzz Media.

Pratiwi, T. W. N. P., \& Putra, I. W. (2015). Pengaruh Rasio Keuangan, Ukuran Perusahaan, Arus Kas Aktivitas Operasi Pada Return Saham. E-Jurnal Akuntansi Universitas Udayana, 11(2), 531-546.

Prayosho, indra sari, \& Hananto, H. (2013). Pengaruh sustainability reporting terhadap abnormal return saham pada badan usaha sektor pertambangan yang terdaftar di BEI periode 2010-2012. Jurnal Ilmiah Mahasiswa Universitas Surabaya,2(2), 1-12.

Putra, I. W. K., \& Dana, I. M. (2013). Pengaruh Kondisi Ekonomi Dan Kinerja Keuangan Terhadap Return Saham Perusahaan Food And Beverages Di Bursa Efek Indonesia. E-Journal Akuntansi Universitas Udayana,5(3), 31703194. 
Putra, L., Febriyansyah, Nurlaela, S., \& Samrotun, Y. C. (2018). Effect of Return on Asset, Return on Equity, Debt to Equity Ratio to Return Stock Company Property and Real Estate In Indonesia Stock Exchange. The 2nd ICTESS 2018, 133-140.

Saragih, J. (2018). The Effects of Return on Assets (ROA), Return on Equity (ROE), and Debt to Equity Ratio (DER) on Stock Returns in Wholesale and Retail Trade Companies Listed in Indonesia Stock Exchange. International Journal of Science and Research Methodology, 8(3).

Setiyono, E., \& Amanah, L. (2016). Pengaruh Kinerja Keuangan Dan Ukuran Perusahaan Terhadap Return Saham. Jurnal Ilmu Dan Riset Akuntansi, 5(5), $1-17$.

Sugiyono. (2017). Metodologi Penelitian Kuantitatif, Kualitatif, dan RED. Bandung: CV Alfabeta.

Tandelilin, E. (2010). Portofolio dan Investasi Teori dan Aplikasi. Edisi pertama. Yogyakarta: Kanisius.

Weston, \& Copeland. (2010). Manajemen Keuangan Jilid 2. Jakarta: Binarupa Aksara Publisher.

Wijaya, M. S. (2017). Pengaruh Sustainability Report Pada Reaksi Pasar dengan Kinerja Keuangan Sebagai Variabel Kontrol. E-Jurnal Akuntansi Universitas Udayana. 